\title{
Environmental Strategies and Preservation of Ancient Traditions in Contemporary Japanese Gardens with Focus on “Suzaku no niwa” (朱雀の庭) “Red Phoenix Garden” in Kyōto and “Suikei-en”「水景園」 "Water Mirror Garden" at Keihanna Commemorative Park, Nara Prefecture
}

\section{Vides stratēǵijas un seno tradīciju saglabāšana mūsdienu japānu dārzos: "Sarkanā fēniksa dārzā" Kioto un "Ūdens spoguḷa dārzā" Keihanna Memoriālajā parkā, Naras prefektūrā}

\author{
With support from Japan Foundation \\ Ar Japānas Fonda atbalstu \\ Agnese Haijima \\ University of Latvia \\ Faculty of Humanities \\ Visvalža iela 4a, Riga, LV-1050 \\ E-mail: agnese.haijima@lu.lv
}

\begin{abstract}
This article is dedicated to two contemporary gardens: "Suzaku no niwa" (朱雀の) “Red Phoenix Garden" in Kyōto and “Suikei-en”「水景園」 “Water Mirror Garden” at Keihanna Commemorative Park, Nara Prefecture both designed by landscape artist Yoshida Masahiro 吉田昌弘. The author analyses the gardens from the aspect of incorporation of environmental strategies in contemporary Japanese gardens, as well as preservation of ancient traditions and merging them with new technologies and innovative approaches.
\end{abstract}

Keywords: contemporary, Japanese, garden, environmental strategy, tradition, innovation.

\section{Introduction}

Quite apart from widely renown traditional Japanese gardens, in recent decades, a number of modernized gardens have been created in Japan that entwine the ancient traditions with new materials, approaches, concepts, as well as traditional and contemporary environmental strategies. This article will explore contemporary Japanese gardens that incorporate such strategies for environmental protection as preserving or creating habitats for wildlife, protection and research of endangered species, recovery of land with industrial waste, reducing the pollution 
in densely populated cities, environmental education of younger generation, and others.

If the traditional gardens have attracted attention of numerous scholars and inspired plenty of existing research, the contemporary gardens have remained largely unnoticed both by scholars and visitors.

Even though in recent decades Japan has seen creation of gardens with outstanding mastery, the places that will be visited and appreciated by the next generations, currently these are little known to visitors. This article will try to introduce two of these masterworks - "Red Phoenix Garden” (朱雀の庭) in Kyōto and “Water Mirror Garden”「水景園」 at Keihanna Commemorative Park in Nara prefecture, designed by landscape architect Yoshida Masahiro吉田昌弘.

The author of this article was surprised about the fact that despite his excellent work, no academic research on him or the gardens designed by him exists, an only exception is his own rather formal and short written description of the "Red Phoenix Garden". This posed certain problems in the research of this topic, since the author had to rely largely on her own observations when visiting and inspecting the gardens, the information obtained from the park guide, official websites and a small number of available written resources.

Landscape designers separate two notions: Japanese style gardens from parks that involve international elements in the garden art. Although in some cases it is quite difficult to draw a clear line, since many of the modern parks in Japan have a sector which is designed as a traditional garden, and traditional gardens also have employed methods used for environmental protection.

\section{“Red Phoenix Garden” - “Suzaku no niwa” (朱雀の庭)}

The author of the article visited "Red Phoenix Garden" on a pale and cloudy early winter day - December 7,2019. Frostbitten maple leaves were scattered on the ground. Despite the cold winter season, the garden had not lost its beauty. On the other side of the central pond, the daisies were still blooming, water cascades mirroring the sky can be enjoyed in any season here (Pic. 1).

Although this place is only a 15 minute walking distance from the Kyōto station, there were only a few visitors. Unusual silence and peace offered by the place are difficult to find in the centre of Kyōto, which is usually densely packed with tourists.

“Suzaku no niwa” (朱雀の庭) - the “Red Phoenix Garden” is located in Umenokōji park (梅小路公園), only one kilometre from Kyōto station. Kyōto City Zoo is also located in the territory of Umenokōji park. Despite its vicinity to the central Kyōto, "Red Phoenix Garden" is relatively little known not only to foreigners but also amongst Japanese.

This is a historical location, since the garden is found in the southwestern part of the ancient Heian-kyō 平安京capital founded in 794. Probably its unique location is the source of its name - Suzaku 朱雀 - the Red Phoenix, that was one of the four cardinal direction guards and was responsible for protecting the direction of South. The ancient capital was laid out following the geomantic principles of 
feng shui and cardinal direction guards were one aspect of this theory. Suzaku was the name of the central avenue in the ancient Heian-kyo capital. Another explanation of the name might be the belief that phoenix is able to raise from its ashes. If phoenix is the power of Nature, then it could be the symbol of Nature's ability to restore itself. The garden built on the industrially polluted land is a vivid example of Nature being able to renew itself.

During the Meiji period (1868-1912), there was a cargo train station, but after it was closed, the site was abandoned and the land - devastated. Landscape architect Yoshida Masahiro applied contemporary technologies for restoring brownfield into a flowering garden.

In 1994, on the occasion of the $1200^{\text {th }}$ anniversary of the Heian capital, efforts were made to relinquish this industrially polluted territory to nature and to restore that what was once destroyed. In 1994, this place served as the exhibition area for the Japan National Green Urbanism exhibition - Kyōto Fair. This garden was constructed as a model in landscape architecture and intended to display both the tradition and innovation in garden art.

The garden features landscaping techniques and methods unique to Kyōto, which have been developed over its long history. ${ }^{1}$

To enter the "Suzaku no niwa" garden, one must pass an entrance garden "Midori no yakata" that joins exterior and interior, which is a typical feature in Japanese garden art. The entrance structure is made of steel-enforced wooden pillars and joints resembling Japanese traditional architecture, but at the same time constituting a diversion from the tradition by adding metal parts to ensure the stability of the building. Further, ornamental glass and decorative tiles mark another departure from the tradition (Pic. 3, 4).

On the right side, an unusual tsubo 壶 garden is constructed, with a stream running through it - yūsen no tsubo (湧泉の传) (Pic. 2). Not only the stream, that is rarely found in tsubo gardens, but also the stones themselves are unusual. Traditionally, Japanese gardens contained only natural stones or shizenseki, 自然石 but here kiri ishi 切石 or artificially cut stones have been used. Horizontal natural stone plates are cut in pieces and arranged vertically. Although artificially cut stones are generally not considered as attractive as natural ones, they are arranged in a visually pleasant and unusual way. As a result, the composition both surprises and delights the eye. Some plants add green dots to this design (Pic. 2).

After being enraptured and moved by the tsubo garden, the next space open to the visitor is the garden area called Momiji dani 紅葉谷 - Red Maple Valley. The view to this garden area opens from the Yūzuki hashi 夕月橋 Evening Moon Bridge (Pic. 3). The scenery of this part was modeled after the famous red maple viewing place in Kyōto outskirts - Takao 高尾. The maple trees themselves were brought from the Takao region because these maples Takao kaede 高尾楓 have the brightest red colour in autumn season. The bright red colour is contrasted with

1 Garden guide. Available at: https://www.Kyōto-ga.jp/umekouji/area/pdf/suzaku-inochi_eng. $p d f$ [accessed May 11, 2020]. 
lush green of the Kitayama cedars Kitayama sugi 北山杉 - another favoured species of $\operatorname{cedars}^{2}$ (Pic. 5).

After crossing the Evening Moon Bridge, one enters in the spot from where opens a view onto the three parts of the main garden: the forest area - 「山辺」, meadows「野辺」 and pond area or art area - 「芸」 (Pic. 15).

The forest area on a hill that surrounds the garden creates a natural border and covers the view of the ugly industrial surroundings of the garden - on one side, a busy railway lines pass, on the others - factories, storehouses and skyscrapers. The tall trees not only cover unpleasant views, but also serve as a sound barrier shielding the garden from the nearby railway. The forest area is dominated by the red pine or akamatsu 赤松, named after its red trunk. Akamatsu once (50-60 years ago) were quite common in the outskirts of Kyōto, but recently have become very rare. This forest area reminds the visitor of the past natural beauties (Pic. 6).

A narrow path leads the visitor from the hill to the pond side (Pic. 12). The pond is called “Mizu kagami”「水鏡」- “Water Mirror" (Pic. 7). The bottom of the pond is laid with mikage ishi 御影石 stones brought from India. The water is only $1 \mathrm{~cm}$ deep. It flows forming cascades. In certain areas, the bottom stones are raised in the water level, thus creating a curved stripe design (Pic. 8). Tobi ishi 飛び石 of the Mirror Pond are square, artificially cut, and that is a departure from the tradition (Pic. 9). On the other side of the pond stretches a field of daisies still blooming despite the season - it is the middle of December. In the traditional gardens, blooming flowers were not introduced, besides, these flowers have been imported from the West. On the other side of the pond grow saru suberi 百日紅 trees that open bright red flowers in July and August.

Inside the pond area lies a glass stage - garasu no butai ガラスの舞台, a location for various stage events. Water flows under the glass surface (Pic. 7).

On this side of the pond, the eye is caught by coast design inspired by Rimpa diagonally laid bridges and majestic susugi bentgrass and kuma zasa 隈笹 - kuma bamboo grass on their sides (Pic. 10, 11). The background is formed by stone wall that is shaped in imitation of the byōbu 屏風 screens ishigaki byōbu 石垣 屏風. The building on the other part of the pond partly resembles shinden zukuri 寝殿造り palaces of the Heian period - the main building, which overlooked the garden on the South side. Terraces and platforms built in the western style, glass facade, two floors, steel enforced wooden carcass and other elements attribute it to the contemporary architecture. ${ }^{3}$

By climbing up the same path (Pic. 12), one returns to the forest area. A path through the pine forest leads to another bridge and a pavilion azumaya 四阿on the other side of the bridge (Pic. 6).

Azumaya pavilions were constructed in traditional Japanese gardens to provide a view of beautiful scenery and rest to the visitors. The red foliage of Takao kaede maple trees add bright colours to the cloudy mid-December day. Through the trees,

2 Oral guidance, Red Phoenix Park guide - Shintarō Itō (December 7, 2019).

3 Ibid. 
the look travels towards a magnificent waterfall (Pic. 20). Another winding path down the hill offers a possibility to approach the waterfall by crossing another bridge over the stream.

There are no other visitors, the air is very refreshing, clean. The stream, plants and trees appear to grow naturally, there is no evidence that the garden has been constructed by a human hand and that the location is in the middle of a busy city in partly industrial area. One feels as if walking in the fresh forests with waterfalls and streams in the outskirts of Kyōto. The waterfall of the "Suzaku no niwa" is 6 metres high, and that makes it the highest waterfall in the Kyōto region. From here opens another view of the pond with water cascades (Pic. 13, 14). By the side of the stream, as if unexpectedly finding a mushroom in the forest, one discovers a small lantern, which is the only stone lantern in the garden. The name of the lantern - mizu hotaru tōrō 水蛍灯篭 - water firefly lantern, reminds of the fireflies that once delighted the viewers near rivers and streams but nowadays are very rarely seen (Pic. 16). The architect seems to have avoided placing stone lanterns in his garden, especially in the eye-catching places. This is another departure from the tradition. To light the garden paths in the evenings, small glass lanterns are placed on the sides of the paths. The glass is decorated with sun and moon images that come from the traditional Japanese garden art. In traditional Japanese gardens such lanterns were placed with the image of the sun facing westward, while the moon - eastward, thereby imitating the movement of sun and moon in one day cycle (Pic. 13).

By crossing the bridge, one enters the meadow zone - 野辺. This area is designed by taking inspiration from Heian period tradition in garden art nosuji 野筋, which nowadays is almost extinct. Only a few examples in the whole Japan remain. Nosuji is a land form that imitates the gently sloping meadows between mountains and plains that had mountain streams running through them. In ancient times, such scenes were found in Japan's nature and since Heian times the court aristocrats created gardens by imitating this land form. Court aristocrats used to walk in the nature and collect wild plants (Pic. 15).

In the gardens imitating nosuji are planted meadow plants like kikiyo 桔梗 bellflower (balloon flower platycodon grandiflorum) ominaeshi 女郎花 (patrinia scabiosaefolia), nogiku 野菊 (wild chrysanthemums) and others. In Sakuteiki 「作底記」, nosuji 野筋 is mentioned as a form of dry landscape gardens. In this case, this land form was constructed with stones. In the Muromachi period, a secret book on garden art Teien hitsudensho「庭園秘伝書」一「山水抙野形 図」 “Sansui narabini no gata no zu” nosuji 野筋 has been mentioned as one way of imitating the mountains without laying stones, but instead creating the landscape with wild plants ${ }^{4}$.

Nosuji is another surprise of this garden since it is very rarely seen today. When crossing the nosuji area, one recalls a Japanese poem: It seems that the visitor has been carried to ancient times with meadows and streams.

4 Heibonsha World Encyclopedia, 株式会社平凡社「世界大百科事典」第 2 版 Kabushiki kaisha, Heibonsha, Sekai hyakka jiten. Digital version. 


\section{“Suzaku no niwa”, “Red Phoenix Garden”, Kyōto}

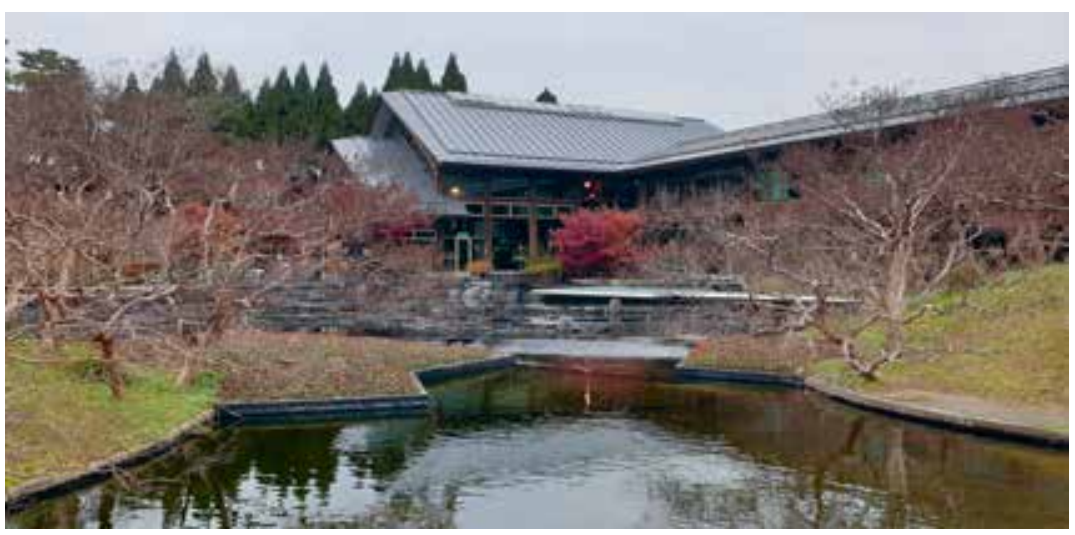

Pic. 1. Central pond, Red Phoenix Garden. Photo by A. Haijima, Dec. 2019

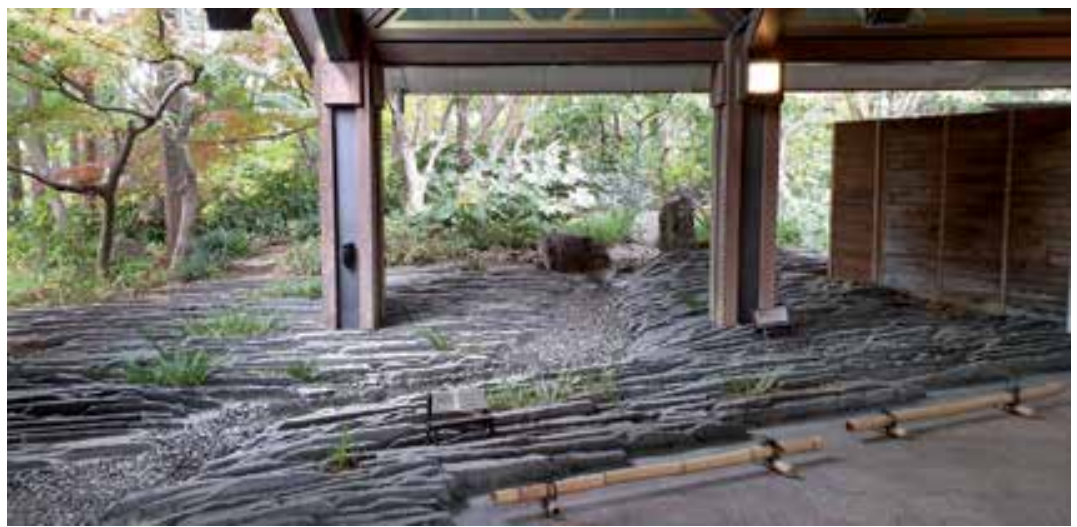

Pic. 2. Tsubo niwa at the entrance, artificially cut stones. Photo by A. Haijima, Dec. 2019

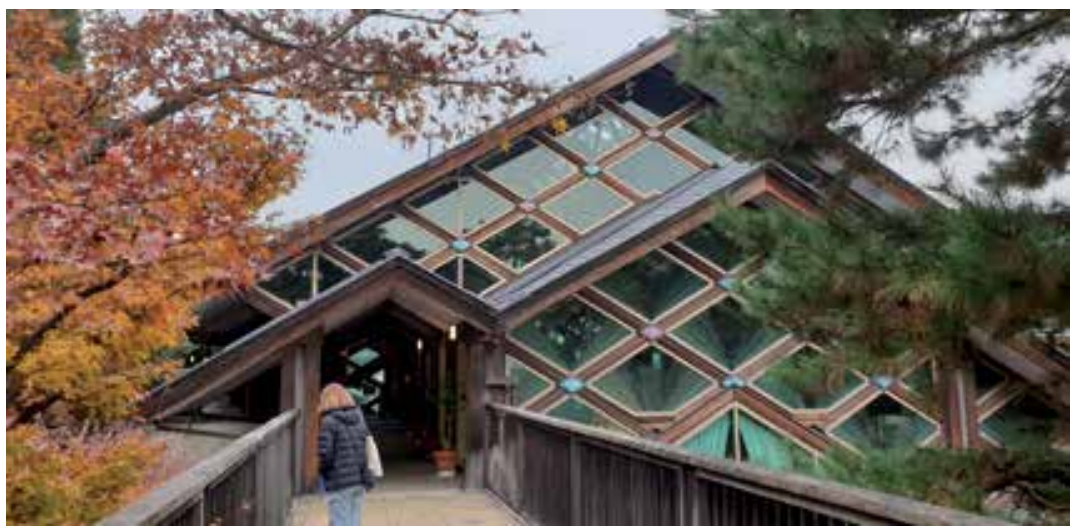

Pic. 3. Evening Moon Bridge connecting Midori no Yakata (garden entrance building) with garden. To the left: Takao kaede - Takao maple trees. Photo by A. Haijima, Dec. 2019 


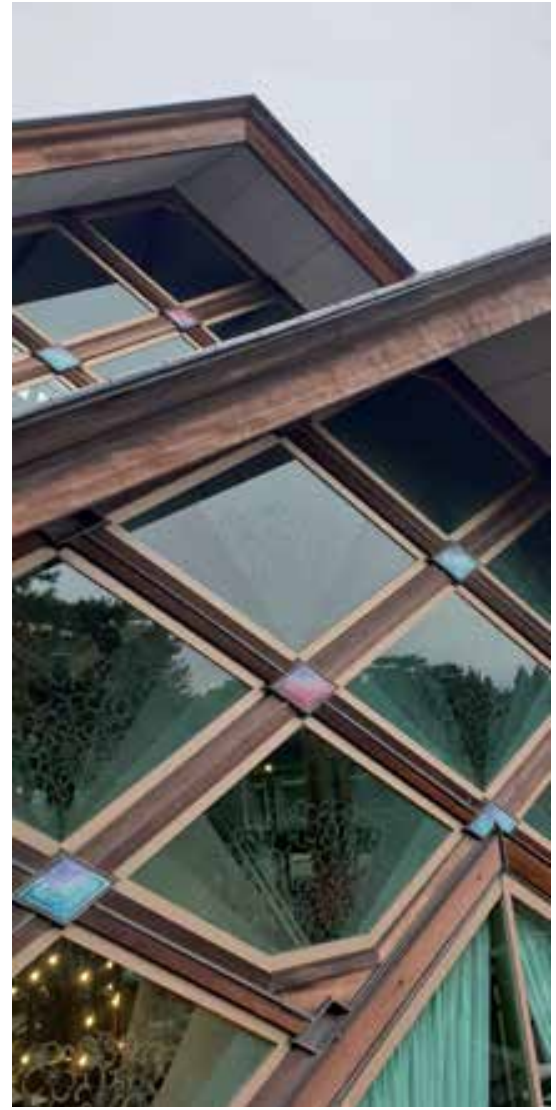

Pic. 4. Detail of the entrance building. Photo by A. Haijima, Dec. 2019

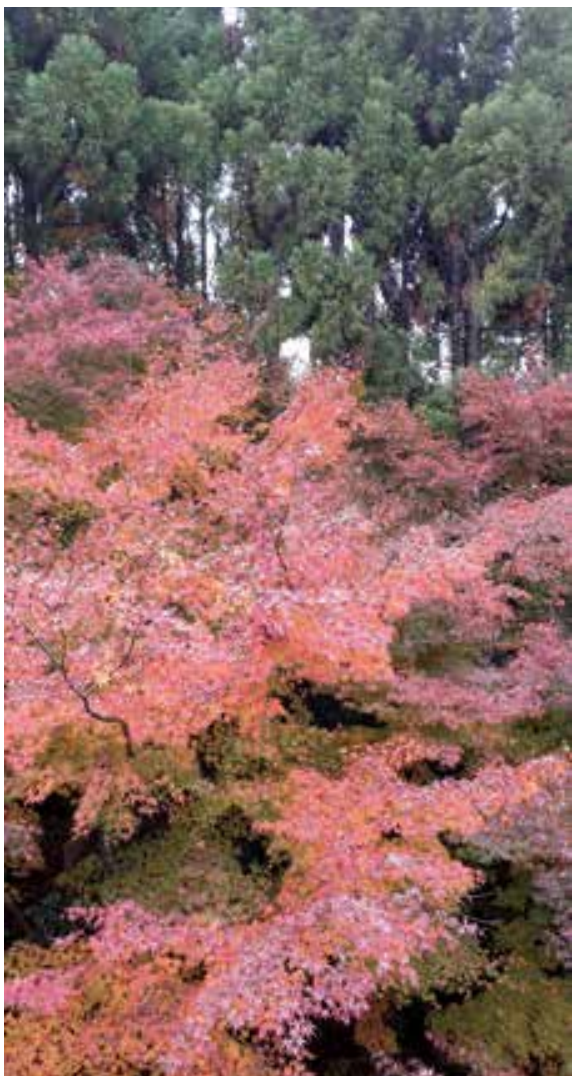

Pic. 5. Takao kaede maple and sugi cypress trees - green and red contrast. Photo by A. Haijima, Dec. 2019

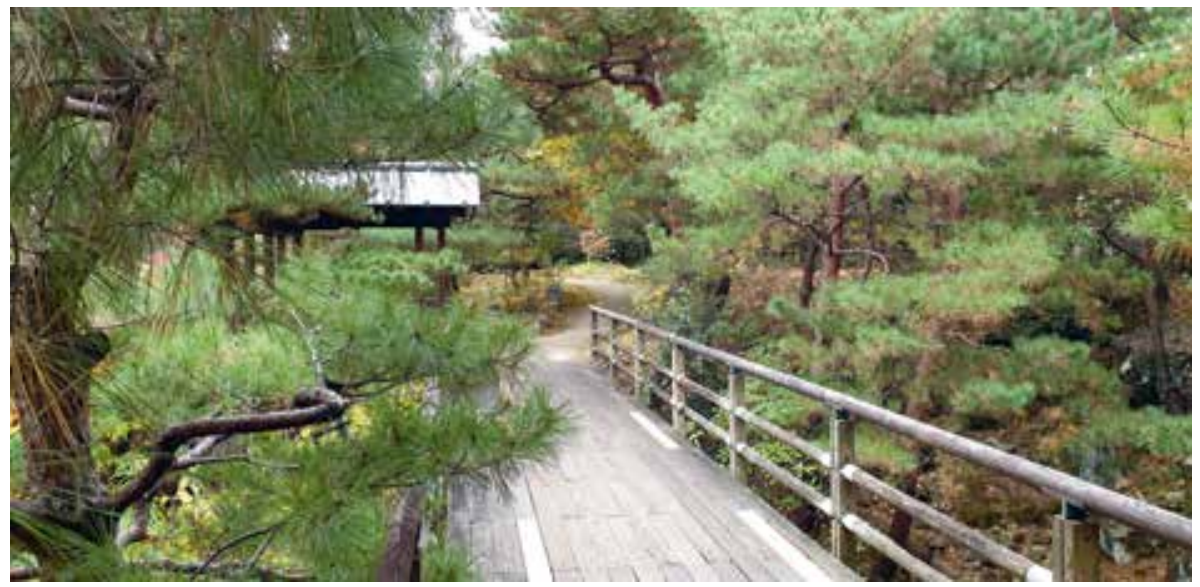

Pic. 6. Wooden bridge leading to the azumaya - the pavilion in the akamatsu red pine forest. Photo by A. Haijima, Dec. 2019 


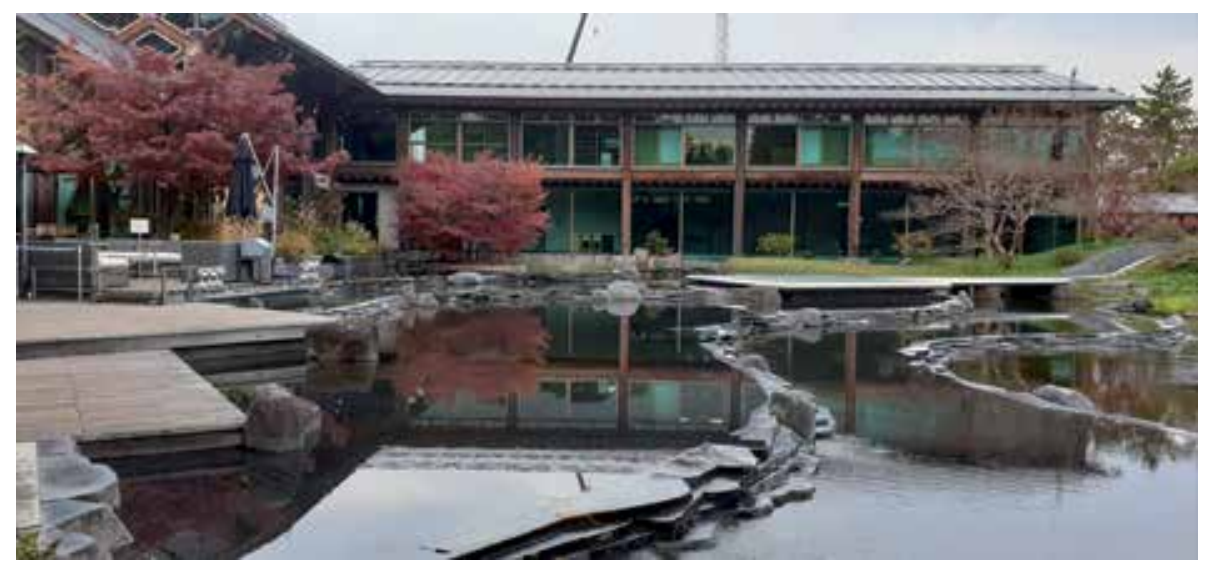

Pic. 7. Water cascades, in the background "Garasu no Butai" "Glass Stage". Photo by A. Haijima, 2019

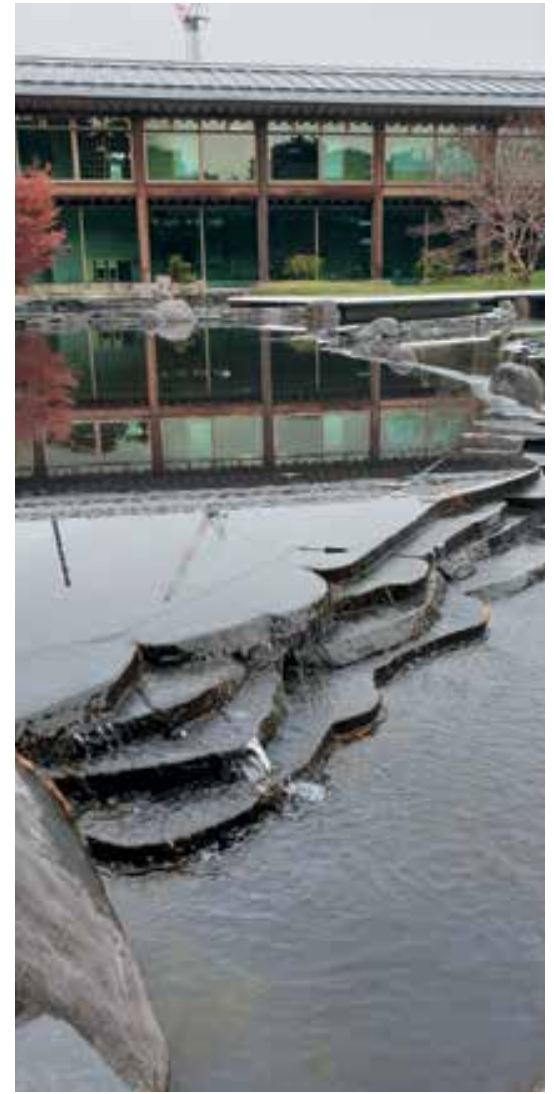

Pic. 8. Mikage ishi.

Photo by A. Haijima, 2019

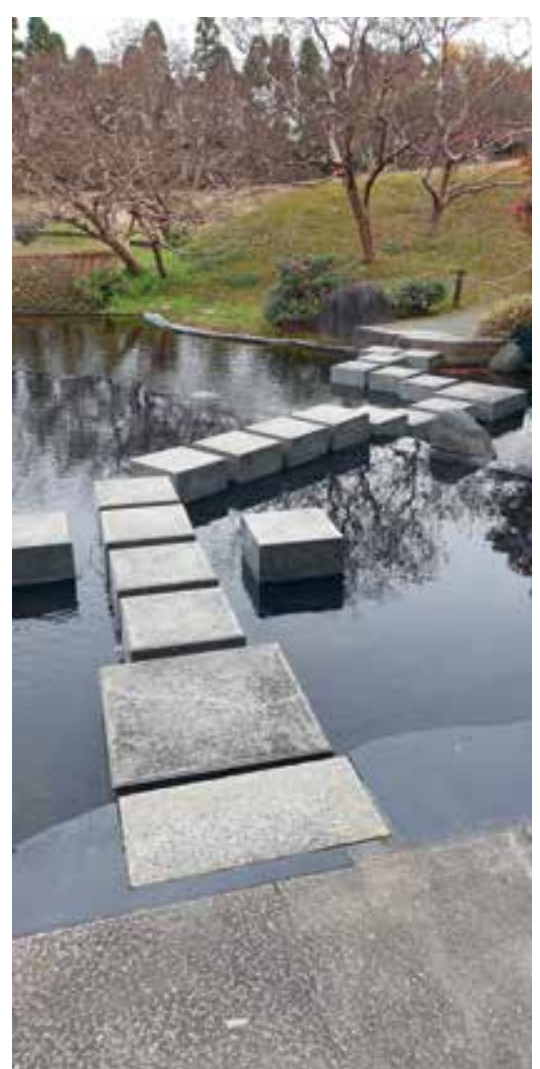

Pic. 9. Artificially cut tobi-ishi, stepping stones.

Photo by A. Haijima, 2019 


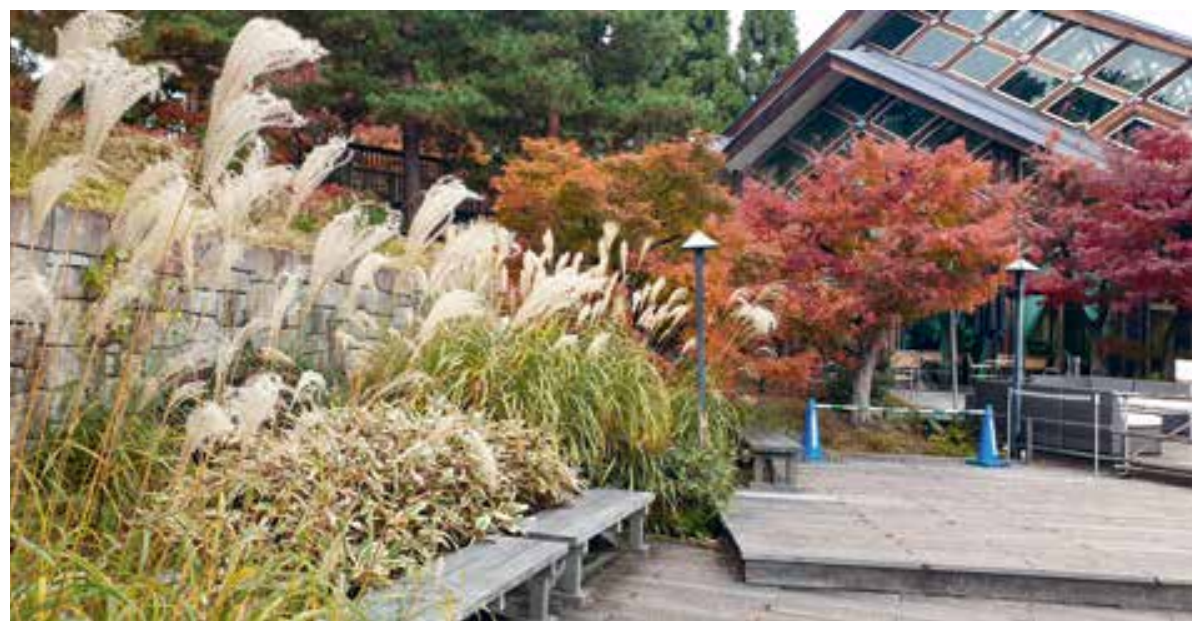

Pic. 10. Diagonally laid bridges - inspiration from Rimpa, susugi bentgrass on the right. Photo by A. Haijima, 2019

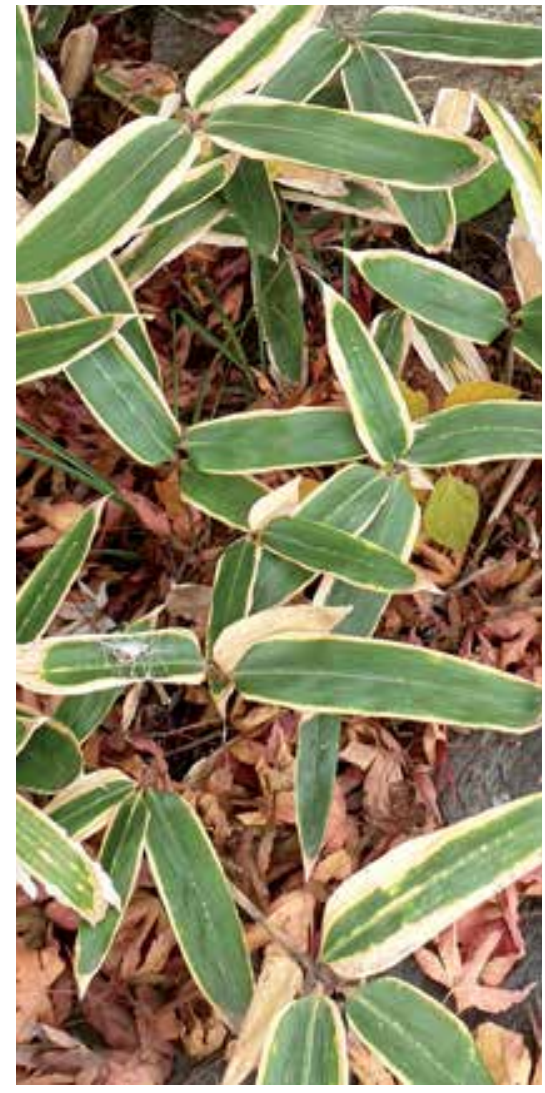

Pic. 11. Kuma zasa 隈笹 bamboo grass. Photo by A. Haijima, 2019

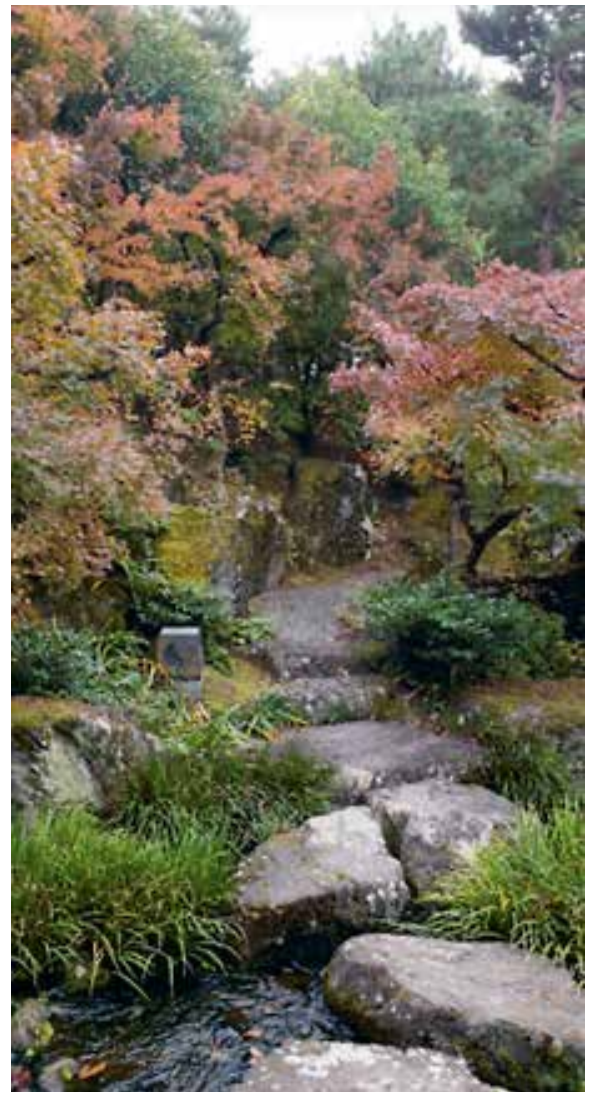

Pic. 12. Garden path and maple trees. Photo by A. Haijima, 2019 


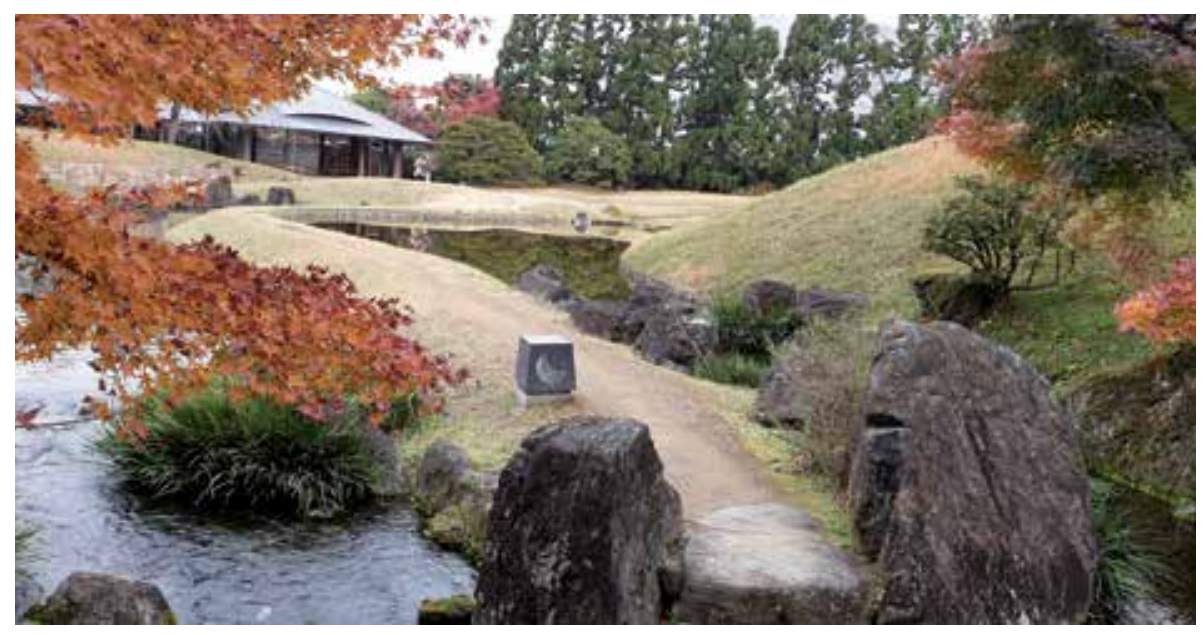

Pic. 13. Streams in "Red Phoenix Garden", moon-shaped lantern. Photo by A. Haijima, Dec. 2019

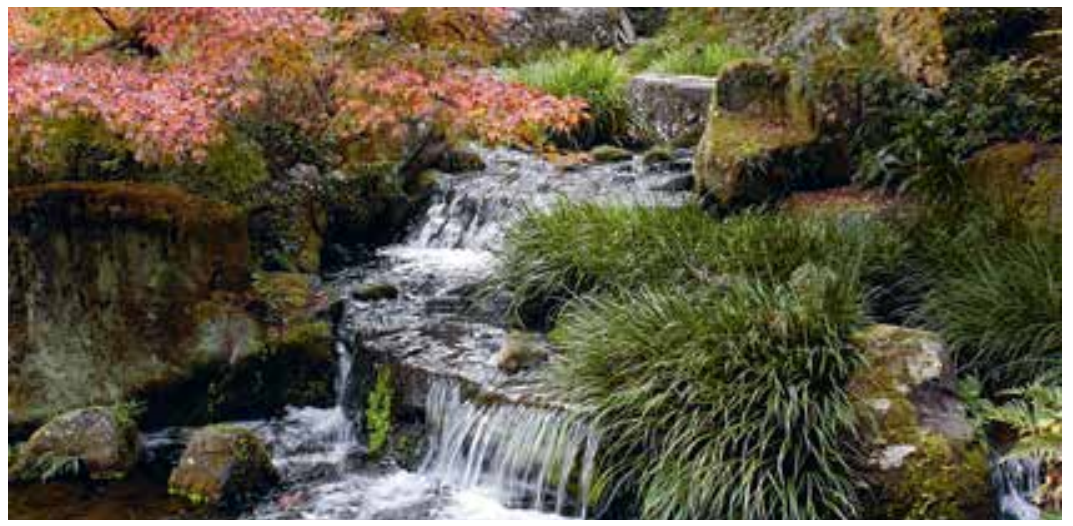

Pic. 14. Water cascades in "Red Phoenix Garden”. Photo by A. Haijima, Dec. 2019

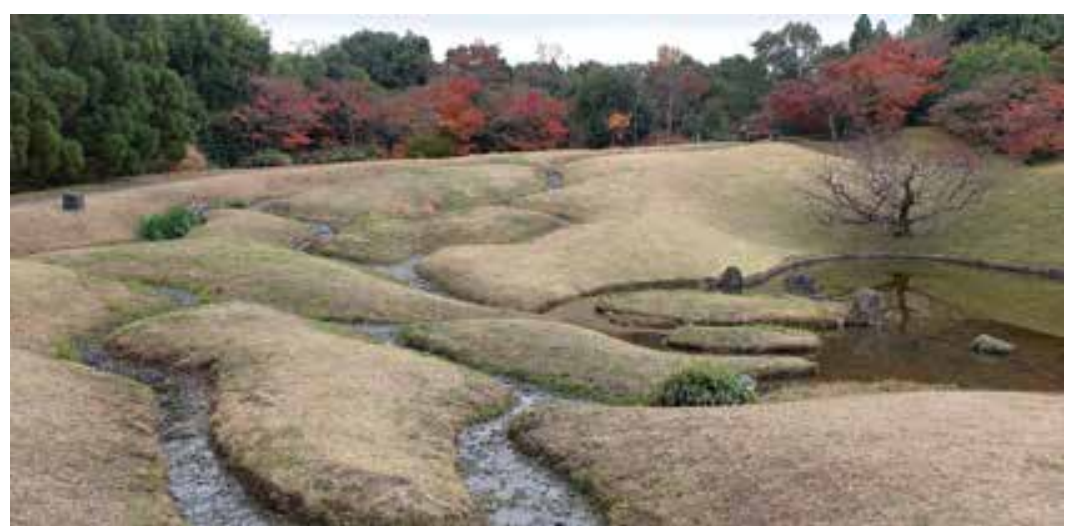

Pic. 15. Nosuji, "Red Phoenix Garden”. Photo by A. Haijima, Dec. 2019 


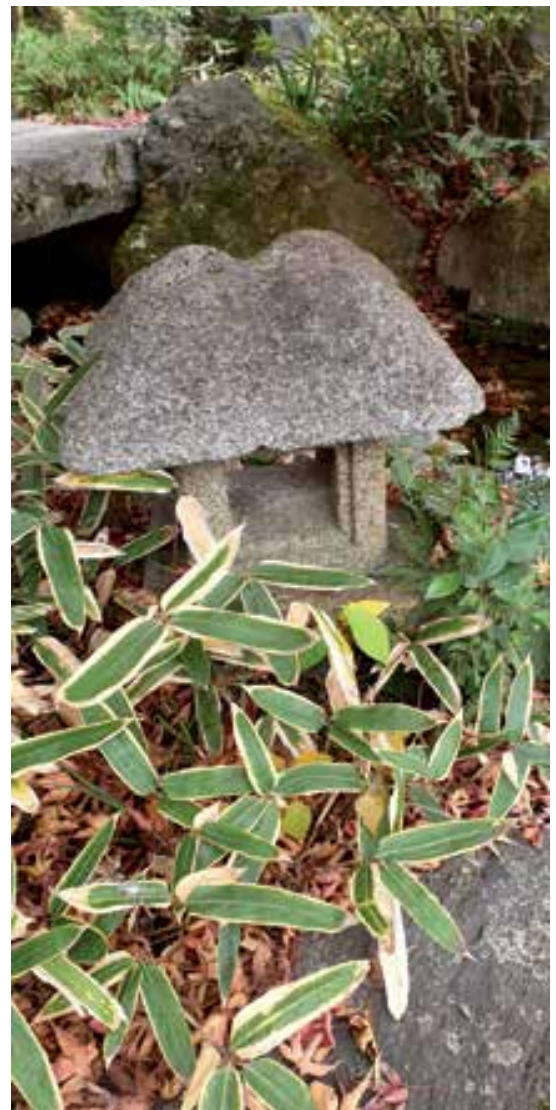

Pic. 16. Mini lantern.

Photo by A. Haijima, 2019

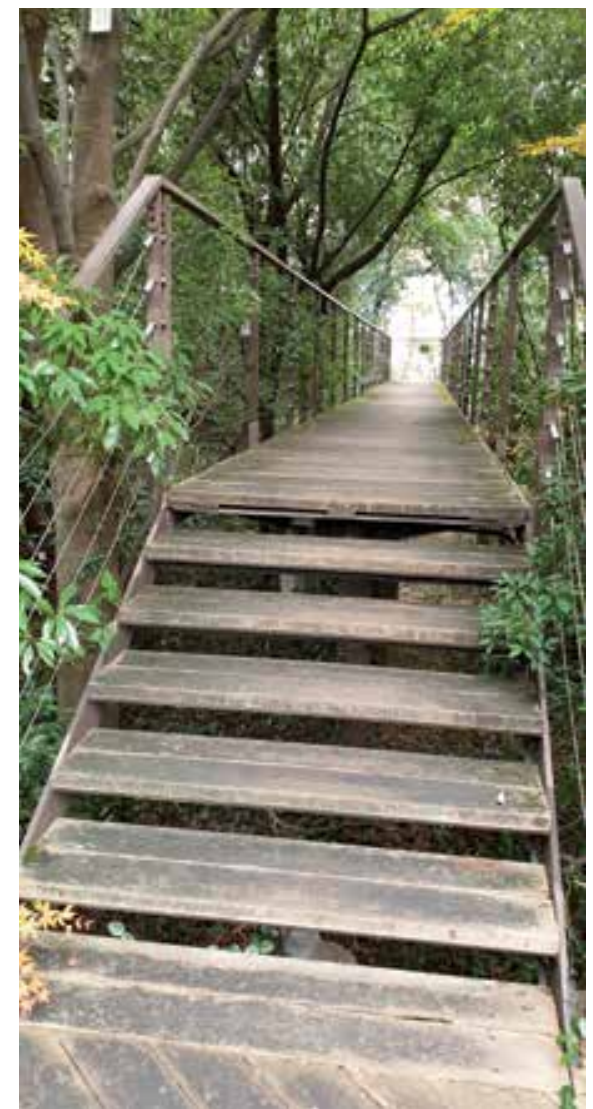

Pic. 17. A bridge leading to Inochi no Mori. Photo by A. Haijima, 2019

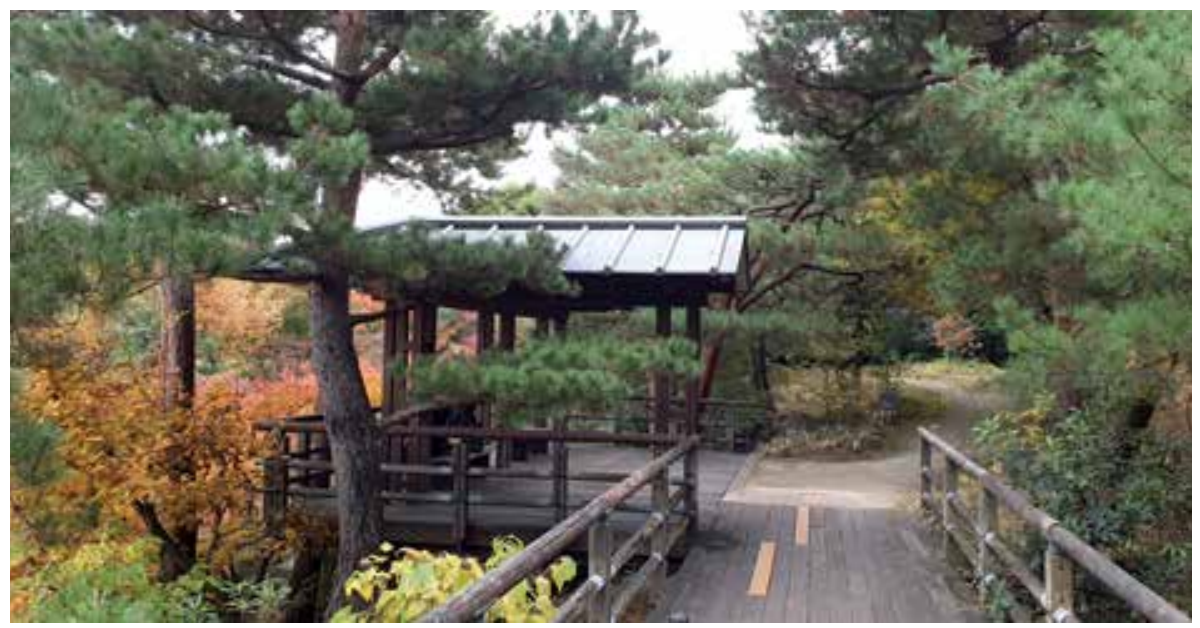

Pic. 18. "Red Phoenix Garden". A view from above. Photo by A. Haijima, Dec. 2019 


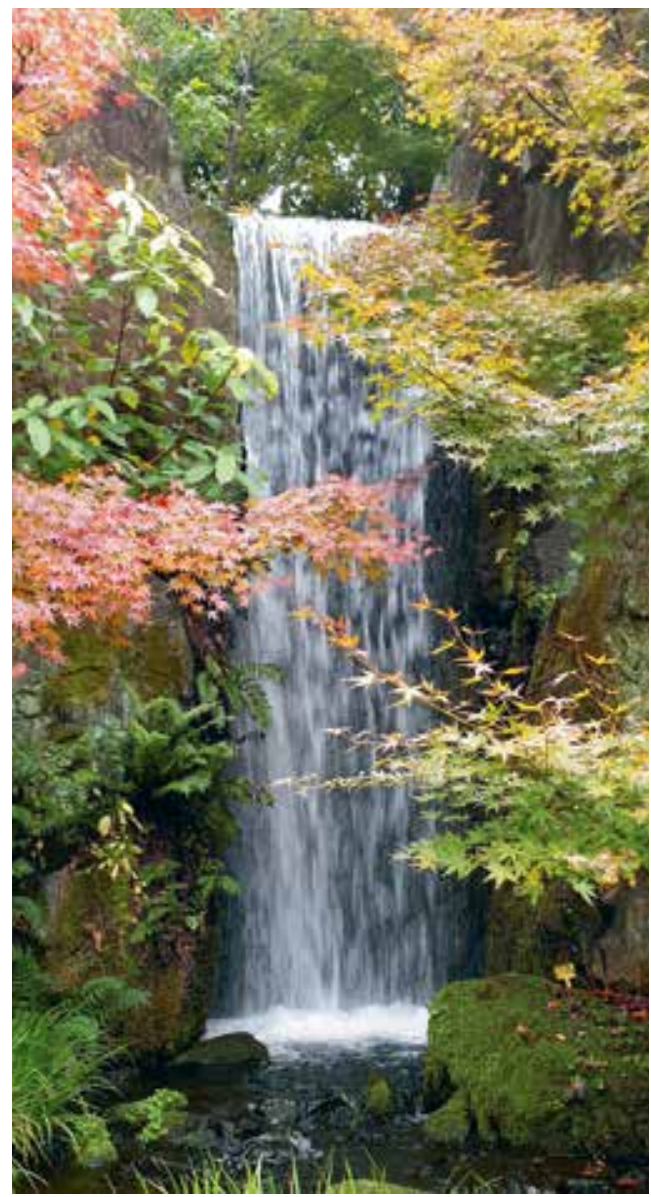

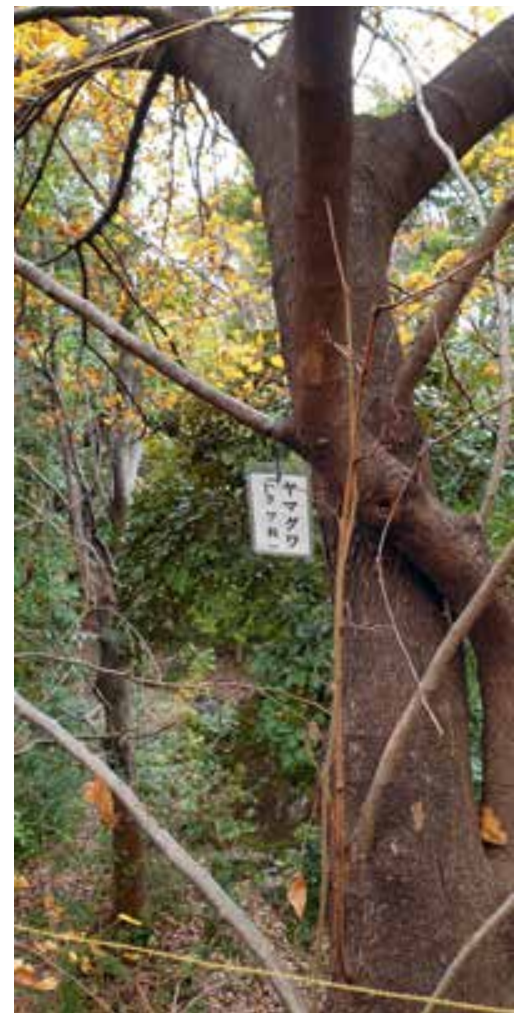

Pic. 19. "Inochi no mori", "Living Forest". Photo by A. Haijima, 2019

Pic. 20. Waterfall.

Photo by A. Haijima, 2019

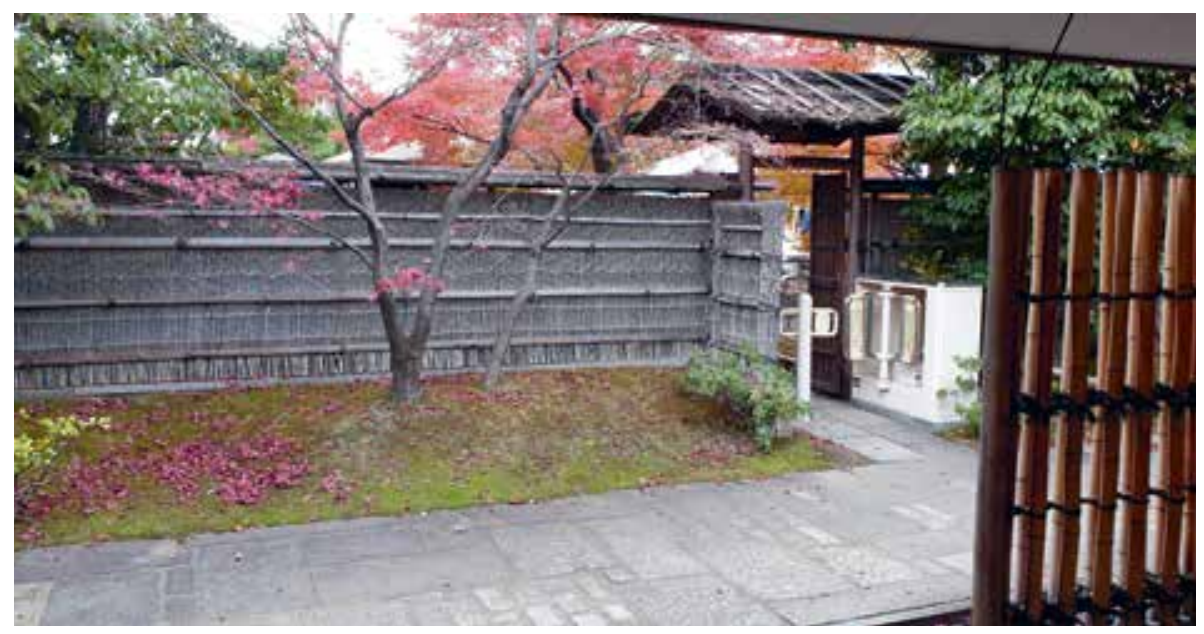

Pic. 21. Section of the Tea Garden. Photo by A. Haijima, 2019 


\section{"Suikei-en” "Water Mirror Garden", Nara prefecture}

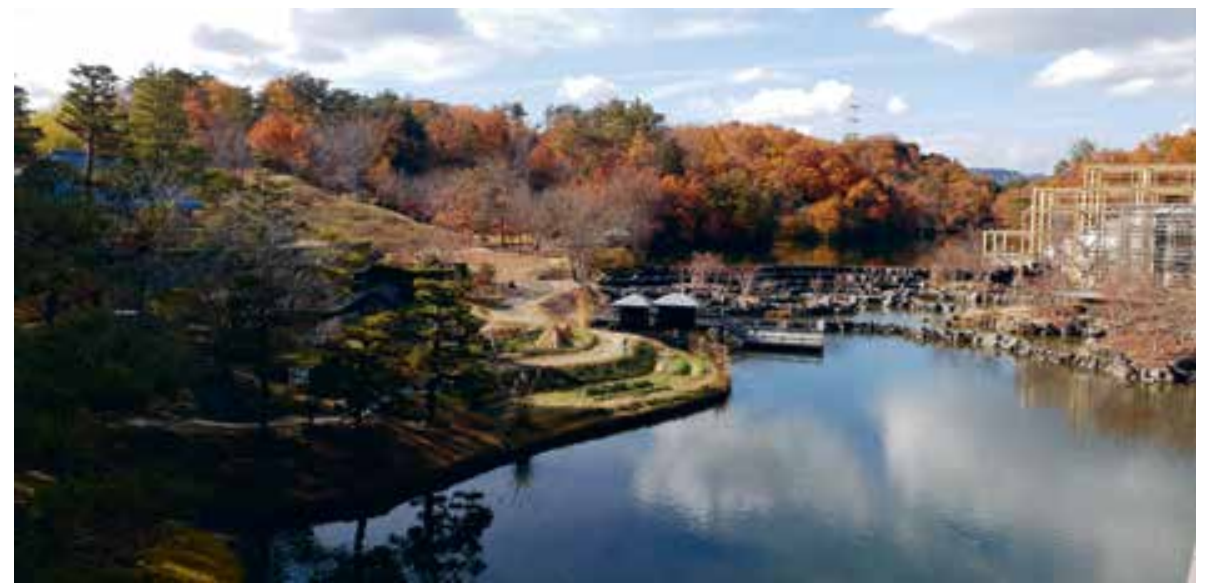

Pic. 22. "Water Mirror Garden". Photo by A. Haijima, 2019

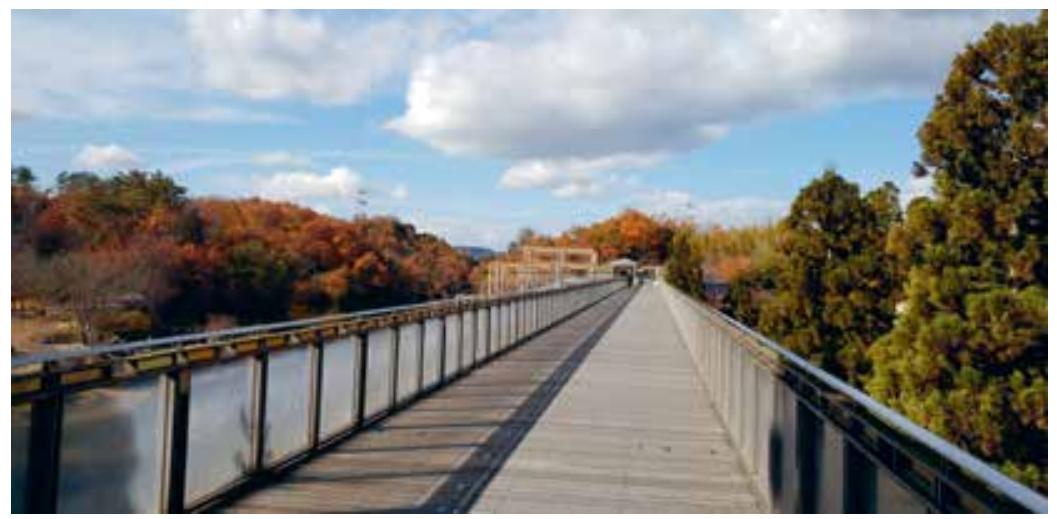

Pic. 23. View from the Kangetsu-rō bridge. Photo by A. Haijima, 2019

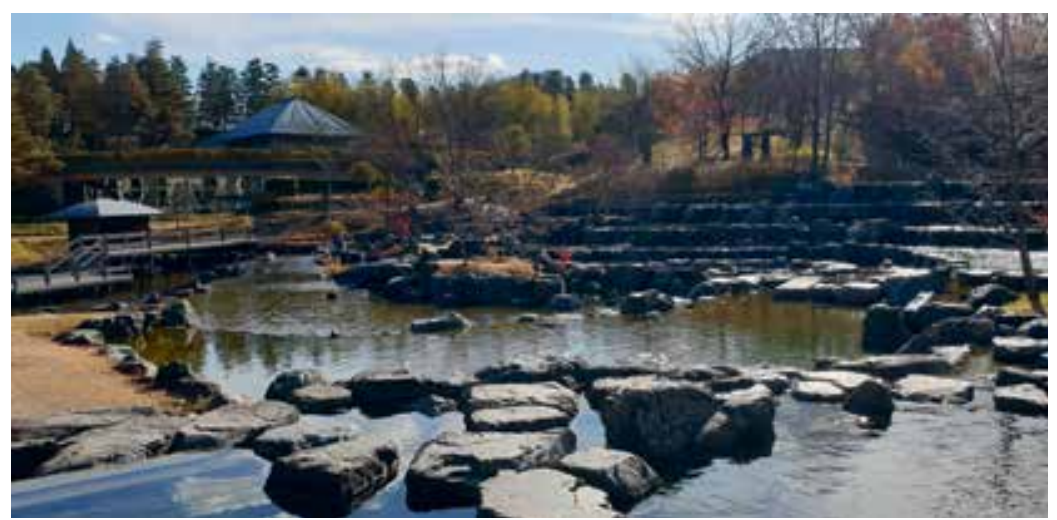

Pic. 24. View of the pond. Photo by A. Haijima, 2019 


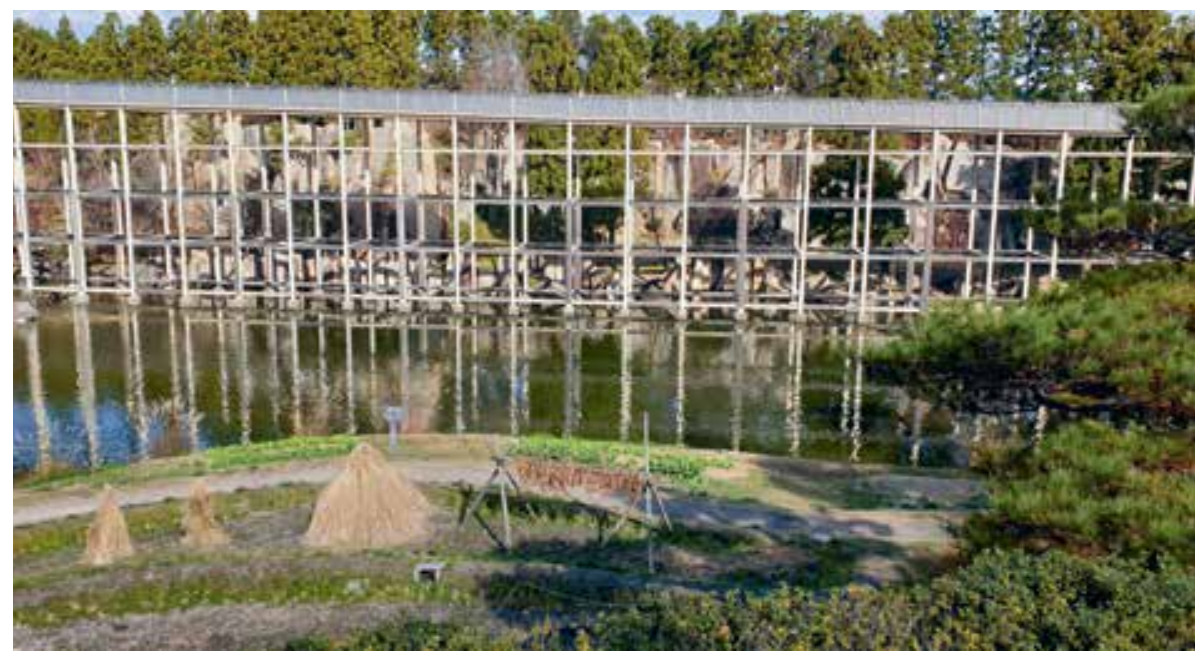

Pic. 25. Satoyama area in foreground. Photo by A. Haijima, 2019

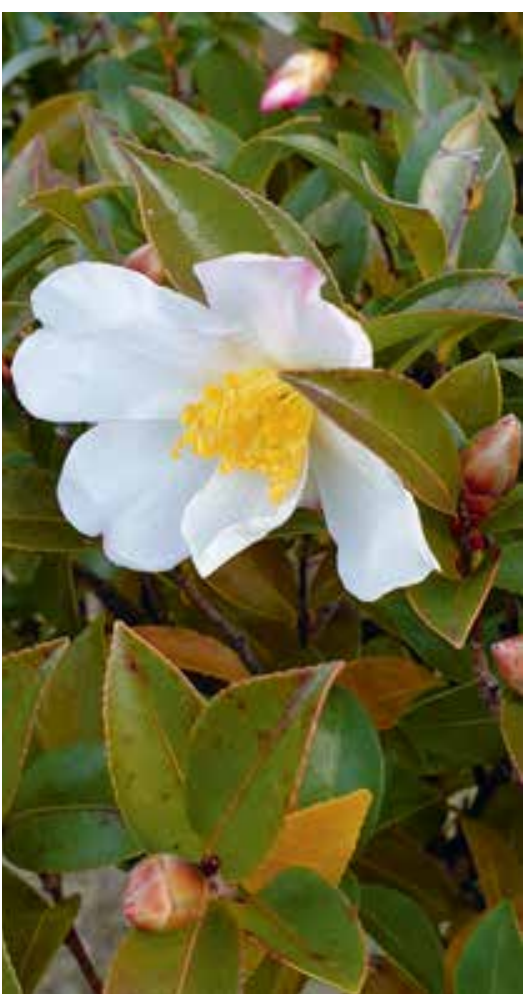

Pic. 26. Camelia.

Photo by A. Haijima, 2019

Pic. 27. Rock Cluster.

Photo by A. Haijima, 2019

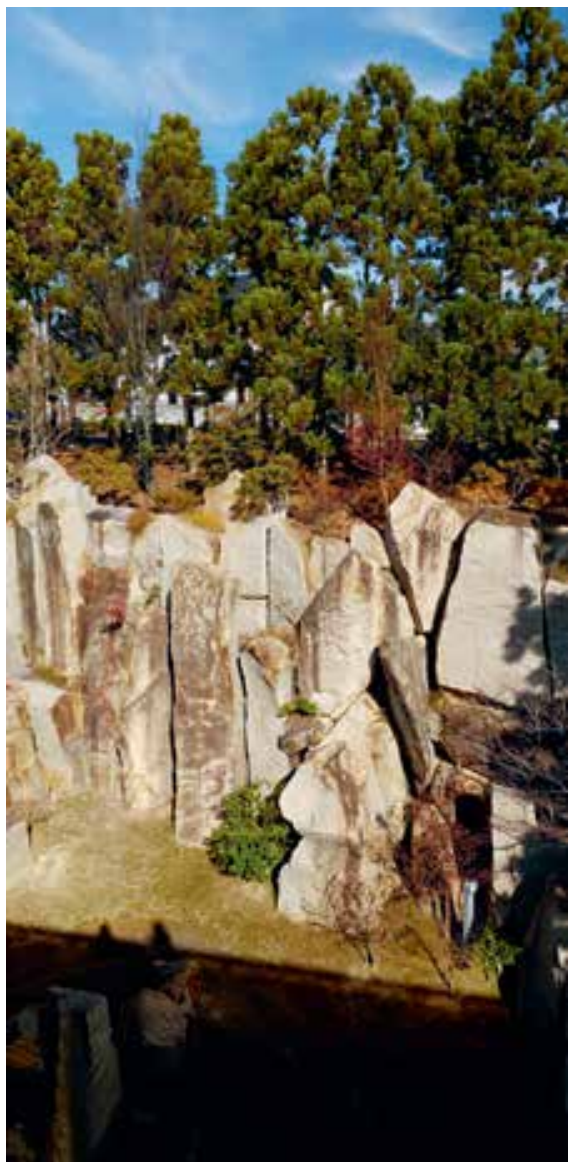




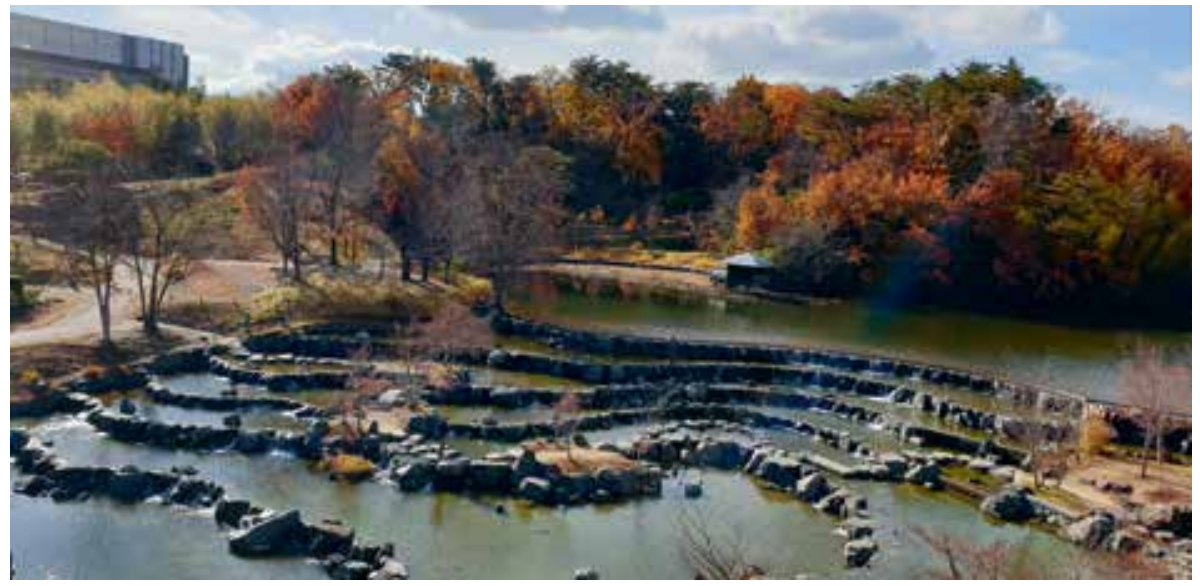

Pic. 28. View of the water cascades, in the background: satoyama and wild forest areas. Photo by A. Haijima, 2019

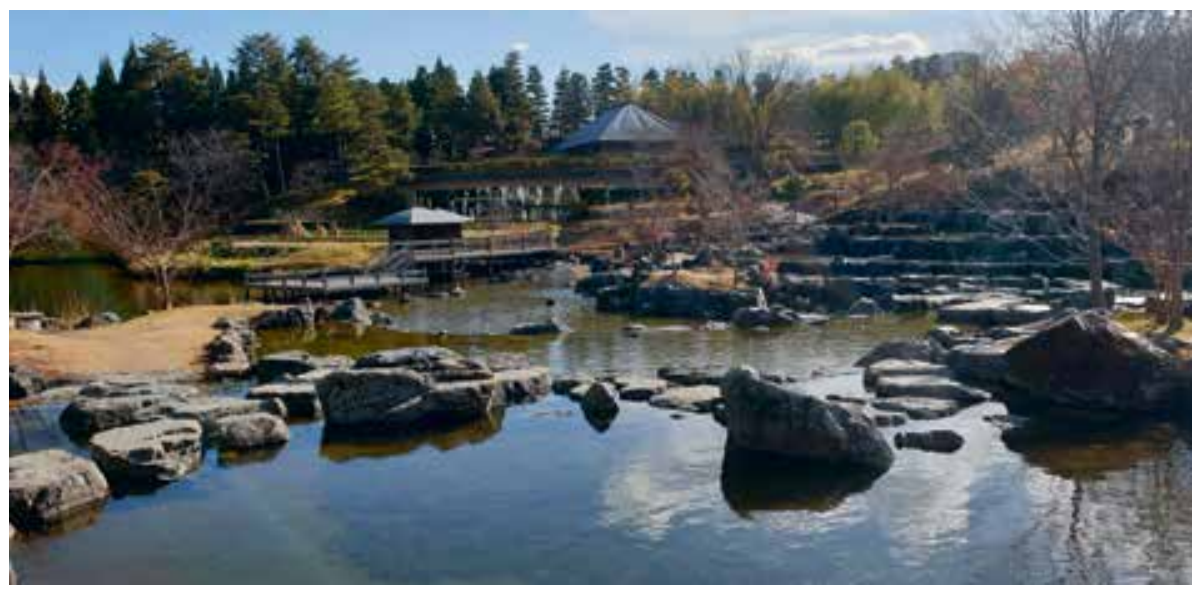

Pic. 29. View of the central pond, in the background - area of satoyama. Photo by A. Haijima, 2019

Pic. 30. Fish in the pond. Photo by A. Haijima, 2019

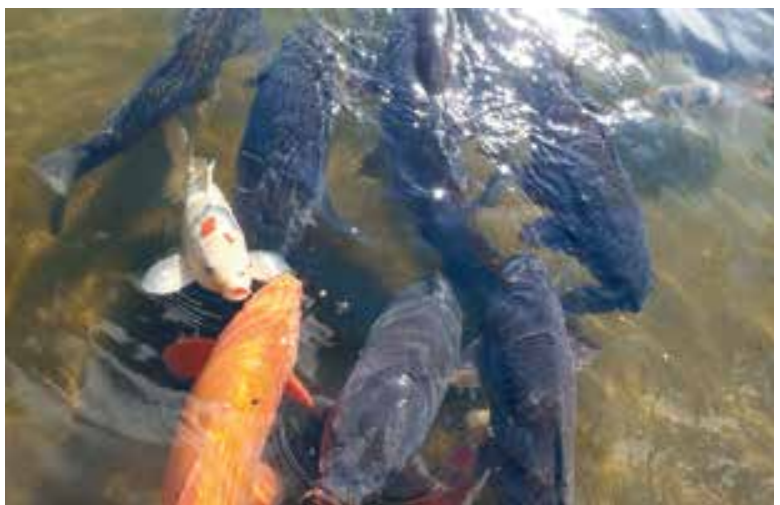




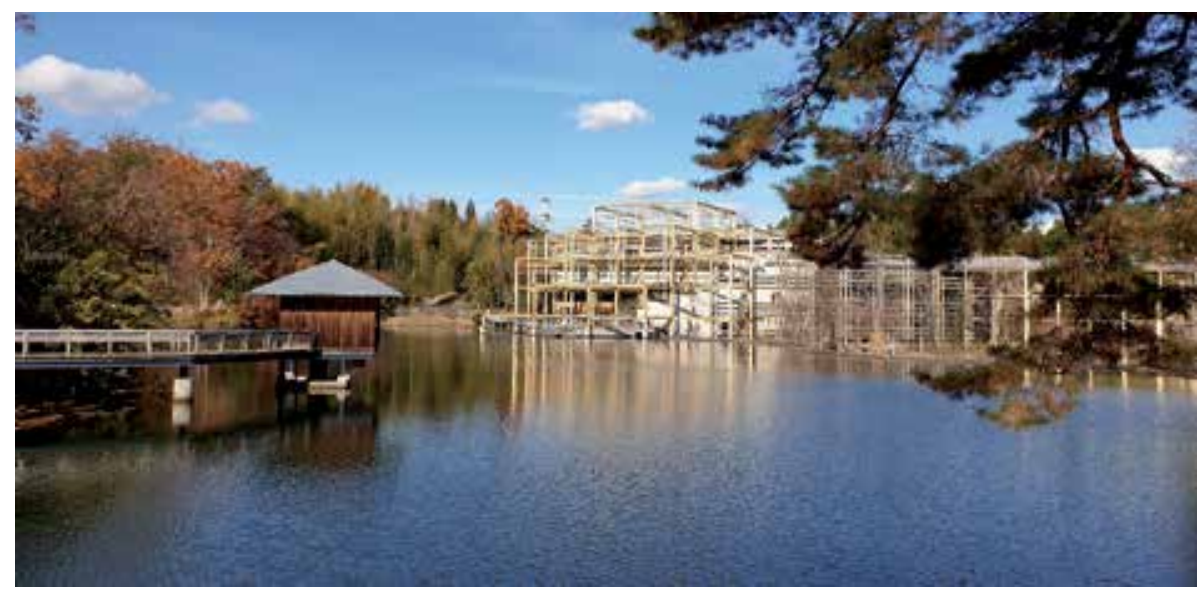

Pic. 31. View of the garden from satoyama area. Photo by A. Haijima, 2019

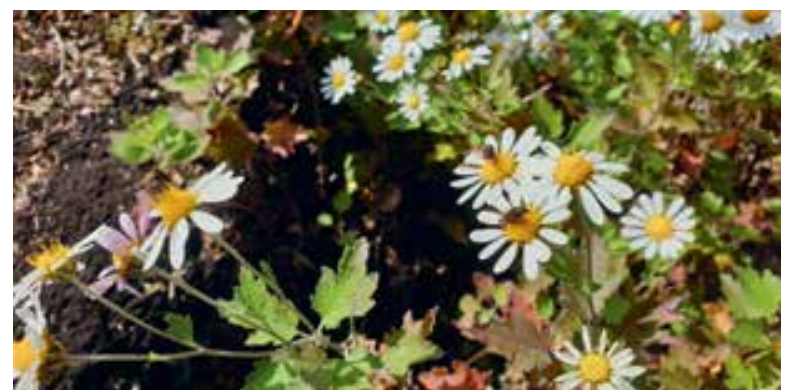

Pic. 32A. Winter flowers blooming in December.

Photo by A. Haijima, 2019

Pic. 32B. A stream with mizukiri ishi (water dividing stone). Photo by A. Haijima, 2019
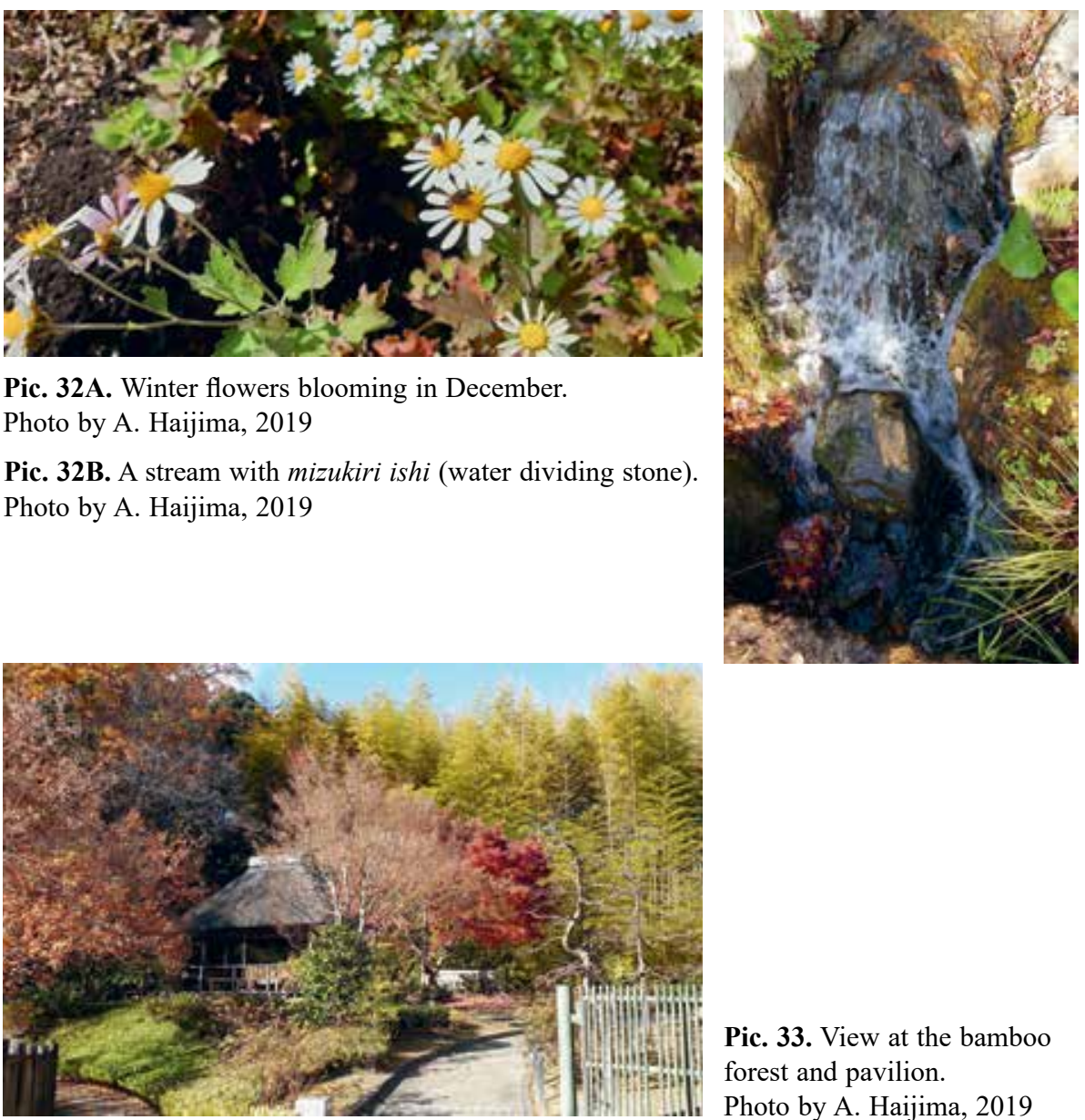

Pic. 33. View at the bamboo forest and pavilion.

Photo by A. Haijima, 2019 
After crossing the meadow area, the visitor arrives at the other side of the pond, and thus has completed a full round along the pond, just like in the traditional kaiyūshiki teien 回遊式庭園 gardens. The last spot open for a view is the garden area with elements from the traditional tea gardens. A remarkable aspect of this area is the bamboo fence and traditional gate that reminds the viewer of the tea culture in Japan (Pic. 21).

This garden has a special area "Inochi no Mori” 命の森 (“Living Forest”) that has been created in the territory of a former freight station, in absence of trees and grass. The aim was to restore biotopes and restore the original flora and fauna that existed here before urbanization. "The Living Forest" occupies the territory of approximately 6000 square metres and was opened in 1996. It can be accessed through a Fumikyō Bridge that connects "Suzaku no niwa" ("Red Phoenix Garden") with "Living Forest". In order to preserve a natural habitat for all forms of life, the visitors walk across a tree canopy boardwalk built 3 metres above the ground. From the boardwalk visitors are able to observe the forest at the height of trees spreading branches (Pic. 17, 19). ${ }^{5}$

Rare birds are found here: Long Tailed Tit, Kingfisher, Owls and others. Rare insects that inhabit this garden include Hawk Moth, Stag Beetle and others. The vegetation includes Japanese Hackberry, Japanese Bush Clover, Kousa Dogwood, Konara Oak and others. ${ }^{6}$

To sum up the above, "Suzaku no Niwa" in Kyōto is a contemporary Japanese garden that has been constructed in an industrially degraded spot in the centre of Kyōto - one kilometre from the Kyōto station on the site of a former cargo train station in the 1990s. It is a successful example of recovering industrially degraded land, which is reinstated to nature and human appreciation. The garden is an interesting example of how ancient traditions can be adapted in contemporary society and merged with technical innovation and creativity.

\section{“Water Mirror Garden” - “Suikei-en”「水景園」}

Another garden - the “Suikei-en”「水景園」 “Water Mirror Garden” was designed by Yoshida Masahiro and completed in 1995. It is located in the Keihanna Commemorative Park (Kyōto Prefectural Kansai Science City Commemorative Park) Nara prefecture, an area that was developed by Japanese government (Pic. 22-24).

"Water Mirror Garden" - "Suikei-en" is an outstanding example of conservation of the beautiful and rare nature spot rich in ancient traditions and history. It is a place where the younger generation can learn about traditional methods of sustainable life, use of natural resources, encounter rare species of flora and fauna,

5 Official Park Guide in English. Available at: https://www.Kyōto-ga.jp/umekouji/area/pdf/ suzaku-inochi_eng.pdf [accessed May 5, 2020].

6 Official Park Guide. Available at: http://www.Kyōto-ga.jp/umekouji/inochinomori/ [accessed May 5, 2020]. 
establish contact with nature and become involved in diverse activities close to nature that contribute to their own physical health and bring social benefit.

"Suikei-en" garden is also notable because here the traditional rural landscape of satoyama 里山 has been preserved (Pic. 25).

Recently satoyama landscapes have been promoted around the world as a global effort to establish "societies in harmony with nature" and as a good model for conservation of biodiversity and human well-being. From 2010, the Satoyama Initiative promoted research on different practices of sustainable use of biological resources, as well as increasing awareness and supporting on-the-ground projects and activities in human-influenced natural environments. Throughout the 1980s and $90 \mathrm{~s}$, the satoyama conservation movement was implemented in Japan. In 2001, there were already more than 500 environmental groups that worked for the conservation of satoyama. Because of their efforts, satoyama has gained prevalence in Japanese landscapes.

The Keihanna Commemorative Park has been created in a landscape of unique beauty - a forested area around two large artificial lakes which was also an area of satoyama villages safeguarding and practising traditional Japanese rural lifestyle. When building the new city, rice fields were given to construction sites of the new city, but part of the forest and artificial lake area was preserved. Traditionally, the two artificial lakes and streams served for water regulation of the rice fields.

"Suikei-en" garden has a sector that has preserved the traditional satoyama landscape with all its practices of Japanese traditional rural lifestyle.

Despite efforts to preserve satoyama, due to the urbanization and overpopulation in Japan, modern technologies that have caused drastic shift in natural resources from charcoal and firewood to oil and the change from compost to chemical fertilizer, as well as because of other factors like aging society, satoyama have become rare in Japan. The disappearance of satoyama has led to threats imposed on many wildlife forms that inhabit these areas. This garden has a sector where the nature is being preserved without human intervention. These parts can be partly observed from distance but not entered.

The location of this garden is unique also from another point of view: it is found in the area that lies in the crossroads of Kyōto, Nara and Osaka prefectures about $30 \mathrm{~km}$ from both Kyōto and Osaka and approximately $10 \mathrm{~km}$ from Nara. The area has been populated already in the Yayoi period, when an agricultural village was situated there. Remains of ancient houses can be seen in the Hatanomae ruins located nearby. Not far from the garden stands the Inayazuma Castle, where the Yamashiro province uprising took place in 1493. The nearby Kizu River historically was an important water transport route that contributed to the economic and cultural development of the area. A number of agricultural villages were located in the territory of the Kizu River basin. In 1931, the villages of Komada, Inada and Hosono were merged into one village - Kawanishi. Subsequently, in 1951, the villages of Kawanishi and Yamadasho also merged, forming the village of Seika. In 1955, Seika achieved the status of a town. Seika is famous for the production of Japanese traditional sweets. Currently, Seika has a population of 36 thousand residents and is the centre of the Keihanna Science City (also 
called Kansai Science City). The city is one of Japan's national projects. The city encompasses the territory of 15 thousand ha and is divided into 12 cultural and science districts with more than 130 research facilities. ${ }^{7}$

The garden covers the area of 24.1 hectares. It is a kaiyūshiki 回遊式庭園 or a stroll garden, which is located around two artificial ponds that are joined together (Nagatani pond) comprises red pine akamatsu 赤松 forest, bamboo forest, konara oak forest, and other elements (Pic. 22-24).

The "Suikei-en" - "Water Mirror Garden" is divided into three zones:

The Satoyama area (Pic. 25), The Rock Cluster (Pic. 27) and the Water Mirror Pond (Pic. 22-24).

Each zone has its character and meaning in the conservation of Japanese traditions, as well as demonstrates innovative approaches in contemporary landscape design and architecture.

"Suikei-en" - "Water Mirror Garden" is a modern style stroll garden kaiyūshiki teien. In contrast to the traditional stroll gardens, it has areas that cannot be found in historical examples. The garden is located in a unique nature spot: two connected artificial ponds - the higher and lower pond that are surrounded by forest, valleys and streams. This picturesque nature spot was also the place of satoyama villages. People living in the area between mountain and pond were engaged in traditional agriculture. Pond water was used to regulate the water level in the rice fields and provide water for the vegetable gardens. Rice fields and small vegetable gardens have become part of the garden scenery. Other areas in satoyama served as fruit gardens. Traditional fruit garden lies at the edge of the pond, next to the rice field. Such areas did not exist in classical stroll gardens. ${ }^{8}$

Another specific feature of this modern garden is the merging of the traditional Japanese garden with secondary nature and a zone of wild nature, where the landscape forms have not been altered (Pic. 28, 29). This is an interesting experiment and approach testifying that in 1990s Japanese were looking for new methods to approach nature and landscape with environmental concern. When the visitor enters the garden, he first arrives at the secondary nature zone, but walking towards the rear end of the garden, he accesses the zone of wild nature. A path runs around the two ponds, connecting all areas. The wild zone contains some places that cannot be entered but only observed from afar. Thus, human activities do not disturb the wildlife habitat. The area covers 24.1 ha, consequently, a full day of hiking is required to visit all spots. An additional advantage of this garden is that it is little known to Japanese and foreign visitors, and here people can enjoy undisturbed walk in close contact with nature. The wild nature zone is called Mebuki no mori - Budding Tree Forest. While walking around the pond in the wild nature zone, beyond enjoying various forms and expressions of wild landscape: red pine forest, oak forest, bamboo forest (Pic. 34) and others, one can also take

Keihanna Commemorative Park. Available at: https://keihanna-park.net/en/ [accessed November 6, 2020].

8 Oral guidance, "Water Mirror Garden" guide - guide’s name is unknown (December 2019). 
a pleasure in observing various types of wildlife: wild water birds, a diversity of songbirds, see fish, rare insects, butterflies and bees. Biodiversity delights the eye.

The garden displays traditional satoyama lifestyle, where nature provided everything to meet people's needs, and nothing was wasted. The bamboo forest lying near the village supplied material for construction and various everyday life items: chopsticks, ladles. Even rice stems after the harvest were dried and used for multiple purposes: making of sandals, ropes etc. Dry fallen branches and trees were gathered, dried and used for heating the houses and cooking. The fallen leaves of the deciduous forest were gathered and served as fertilizer of rice fields. Acorns were fed to pigs. Holes were drilled in oak logs which were suitable for growing shiitake mushrooms. Currently the wild nature zone has a bonfire and forest camping place with a small animal farm on its side. School children visit this area to learn about the sustainable use of natural resources practised by their predecessors.

It is demonstrated how the dried branches that are gathered in a forest are used to make fire. When it has burned out, sweet potatoes are buried in the ash and cooked. ${ }^{9}$

Landscape designer Yoshida Masahiro's masterful techniques are best displayed in the traditional garden that also incorporates a number of new elements. The traditional garden "Suikei-en", which lies at the entrance zone can be visited and viewed in several ways: by walking into it following a narrow and winding path, by observing it from above, from the Kangetsu-rō 観月廊 Moon Viewing Passageway (gallery, bridge) (Pic. 23) or by contemplating it from the other side of the pond.

A distinctive feature of the "Suikei-en" garden is its 10-metre-high bridge stretching along one side of the pond and connecting the entrance with three zones of the traditional garden: The Rock Cluster, the Maple Valley and the Moon Viewing Hall.

The bridge is an interesting device. Apart from its function of providing the picturesque views of the pond, the Rock Cluster, the Maple Valley and the rear Wild Forest zone, it also protects the traditional garden from damage caused by multiple visitors - the garden is viewed from above. The construction of the bridge was inspired by the shogi in Japanese traditional machiya 町家 houses (townhouses). To the author of the article it reminded of the wooden posts of the Kiyomizu temple 清水寺.

Another way to enter the traditional garden is to follow a path winding under the bridge. At the beginning, the path feels its way along tall vertical stone slabs of the Rock Cluster. This zone features high, upright, artificially cut stones form a rock wall as a border zone of the garden (Pic. 27). The composition gives an illusion of the garden being on one side surrounded by a mountain range. Pine trees and other smaller plants are planted in the narrow openings between the rock walls creating a natural cliff image.

The path runs along the rock wall which is not flat but at certain intervals protrudes, thereby obscuring and then opening the view to the scenery, constantly

9 Oral guidance, “Water Mirror Garden” guide - guide’s name is unknown (December 2019). 
keeping the visitor in expectation of a new view and yielding diversified experiences.

Yoshida Masahiro's skill as a designer is not limited to creating diverse layout of the rocks: either as long vertical slabs as if in the cliffs, as stones accentuating the horizontal landscape, or as stones inside the water and many more arrangements, his creative attention is directed at all elements of the garden.

His treatment of water is particularly notable: Yoshida does not leave water only as a flat even surface. By making it flow in different heights, at various speed levels, he creates variations: wide horizontal cascades, high, narrow, vertical waterfalls. Particularly picturesque is the Maple Valley zone. To increase the enjoyment and beauty of the red maples in autumn, the architect has placed water ponds in the area to mirror the bright colours. The flow of water is diversified: through narrow and fast horizontal streams, in calm flat-lying ponds with mirrorlike surface, from vertical cascades and so on. Various devices are used to create the sound of the water: a pebble is placed before the waterfall - mizu kiri ishi 見ず切石 - water dividing stone to create interesting patterns of the water and specific sound, multilayered cascades, high waterfalls all add life and sound to the garden (Pic. 33). Garden can be enjoyed with all five senses: the smell of flowers, the sound of water, birds, wind in the trees, the views delighting the eyes, the feeling of the feet and touch of the hands, body movement through the garden and the taste of its fruit.

The garden is designed to enable the visitors to enjoy it all the year round: sakura, rhododendrons, irises, hyacinths and orchids open their flowers in spring, in the summer heat, visitors rejoice in hydrangeas, irises, lilies, lotus flowers and bush clovers, while in autumn hurricane lilies, chrysanthemums, red maples startle the eye, and even in winter camellias, plums and winter sakuras are blooming.

The author of the article visited the garden in the middle of December, when it could have been the least beautiful, yet the garden offered a number of unexpected surprises: the winter sakura were blooming the yellow, brown, orange and red autumn leaves of the deciduous forests reflected on the surface of the ponds, wild geese were swimming in flocks, countless birds were chirping in the wild forest, carps were swimming in the pond. Sazanka flowers 山茶花 were particularly bright, late autumn flowers were still blooming (Pic. 26, 32).

The garden designed to be pleasant throughout four seasons is a splendid venue for various events according to the season and Japanese customs: sakura blossom viewing in spring, moon viewing in autumn etc.

Thus, the garden with all its diversity fulfils various expectations, meets various tastes, interests and needs.

Another typical feature of Yoshida design is the absence of stone lanterns in the garden. This designer customarily places only one unremarkable little lantern in the garden which has to be found. Usually, the lantern sits like a mushroom under the tree in the rear end of the garden.

A winding path stretches around the garden. In places with a particularly good view the architect has placed the seats for stopping, enjoying the view and resting. 
The road to the traditional garden along the taniai valley is particularly picturesque. The path meanders along the side of the rapid stream.

\section{Conclusion}

Both gardens - “Suzaku no niwa” (朱雀の庭) “Red Phoenix Garden” in Kyōto and “Suikei-en”「水景園」“Water Mirror Garden” at Keihanna Commemorative Park are masterpieces of the same landscape designer and architect - Yoshida Masahiro. They share a number of features that outline certain elements typical of Yoshida in garden design: the use of water as a mirror, central pool or pools that serve as the main element of the composition in the kaiyüshiki type garden, diverse approach to the water, environmental concerns, a single small hidden lantern in the whole garden, a garden that can be appreciated throughout the four seasons all year round, a concern for the garden's role for the local community and society in general. Both contemporary Japanese gardens are good examples of concern for environmental issues, nature preservation and restoring, respect for old traditions and their continuation in a modern form.

\section{LITERATURE}

1. 梅小路公園 朱雀の庭 (Umekōji Park, Suzaku no niwa park guide), Kyōto City Greenery Association. Available at: https://www.Kyōto-ga.jp/umekouji/suzakunoniwa/ [accessed September 28, 8.09.2020].

2. Umekōji Park informative leaflet. Available at: https://www.Kyōto-ga.jp/umekouji/area/ pdf/suzaku-inochi_eng.pdf [accessed May 11, 2020].

3. 朱雀の庭 (Suzaku no niwa), Kukan-soken company, 2010. Available at: http://www. kukan.com/pdf_kukan/topics/03suzakunoniwa.pdf [accessed September 28, 2020].

4. Inochi no Mori. Available at: http://www.Kyōto-ga.jp/umekouji/inochinomori/ [accessed May 11, 2020].

5. Inochi no Mori Guide. Available at: http://inochinomori.sakura.ne.jp/ [accessed May 11, 2020].

6. Keihanna Commemorative Park. Available at: https://keihanna-park.net/en/ [accessed November 6, 2020].

7. Heibonsha World Encyclopedia, 株式会社平凡社「世界大百科事典」第 2 版 Kabushiki kaisha, Heibonsha, Sekai hyakka jiten. Digital version.

8. Oral guidance, "Water Mirror Garden" guide - guide's name unknown (December 2019).

9. Oral guidance, "Red Phoenix Garden" guide Shintarō Itō (December 7, 2019).

\section{Kopsavilkums}

Pètījums veltīts diviem mūsdienu japāṇu dārziem: "Sarkanā fēniksa dārzam" Kioto un "Ūdens spoguļa dārzam” Keihannas Memoriālajā parkā Naras prefektūrā. Abus dārzus ir plānojis dārzu arhitekts Jošida Masahiro. Autore pievērsusies vides stratēgiju un tradīciju pārmantošanas jautājumiem šo dārzu izpētēe, kā arī seno amata prasmju savienojumam ar mūsdienu tehnologijāam un inovatīviem risinājumiem.

Atslēgvārdi: mūsdienu japāņu dārzs, vides stratēgijas, tradīcijas, inovācijas. 